\title{
GAMBARAN PENGETAHUAN PASIEN DIABETES MELLITUS (DM) DAN KELUARGA TENTANG MANAJEMEN DM TIPE 2
}

\author{
THE DESCRIPTION OF KNOWLEDGE OF DIABETES \\ MELLITUS (DM) PATIENTS AND FAMILY ABOUT THE \\ MANAGEMENT OF DIABETES MELLITUS TYPE 2
}

\author{
Ni Wayan Trisnadewi1, I Made Sudarma Adiputra3, Ni Kadek Mitayanti3. \\ Sekolah Tinggi Ilmu Kesehatan Wira Medika Bali ${ }^{123}$
}

\begin{abstract}
ABSTRAK
Pendahuluan: Diabetes Melitus (DM) adalah suatu penyakit degeneratif yang dikarenakan tidak berfungsinya insulin yang ditandai dengan peningkatan kadar gula darah. Penanganan pasien DM tipe 2 dilakukan dengan 4 pilar, diantaranya : edukasi, diet, latihan fisik, dan pengobatan. Keberhasilan terapi untuk pasien DM dipengaruhi oleh pengetahuan responden tentang penyakit DM. Tujuan penelitian ini untuk mengetahui gambaran pengetahuan pasien dan keluarga tentang manajemen DM di Wilayah Kerja Puskesmas Tabanan II. Metode : Metode penelitian yaitu deskriptif kuantitatif, dengan jumlah sampel sebanyak 80 responden. Pengumpulan data menggunakan kuesioner dan didapatkan selama 2 minggu. Hasil : Hasil analisa dengan univariat berdasarkan tingkat pengetahuan pasien tentang manajemen DM tentang edukasi $(65 \%)$, diet $(83,8 \%)$, latihan fisik $(77,5 \%)$ dalam katagori baik, sementara pengobatannya $(61,3 \%)$ dalam katagori kurang. Pengetahuan keluarga tentang manajemen DM yaitu edukasi $(67,5 \%)$, diet $(72,5 \%)$, latihan fisik $(90 \%)$ dalam katagori baik, sementara pengobatan $(53,8 \%)$ katagori kurang. Diskusi : Kesimpulannya bahwa pengetahuan tentang manajemen DM pada penderita DM dan keluarga di wilayah puskesmas Tabanan II belum optimal, sehingga perlu dikembangkan edukasi manajemen yang berkelanjutan dalam pelayanan kesehatan.
\end{abstract}

Kata kunci : manajemen DM, pengetahuan, pasien, keluarga

\begin{abstract}
Introduction : Diabetes Mellitus (DM) is a degenerative disease due to insulin malfunction characterized by elevated blood sugar levels. Handling of patients with type 2 diabetes is done with 4 pillars, including: education, diet, physical exercise, and treatment. The successfully of therapy for DM patients is influenced by the knowledge of respondents about DM disease. This research aimed to know the description of knowledge of patient and family about DM management in Health Center of Tabanan II Working Area. Method : The method of this research is descriptive quantitative, with the number of samples as much as 80 respondents. Data was collected used questionnaires and obtained for 2 weeks. Result : The Result of univariate analysis based on patient knowledge level about DM management about education (65\%), diet (83,8\%), physical exercise $(77,5 \%)$ in good category, while treatment $(61,3 \%)$ in less category. Family knowledge about
\end{abstract}


DM management of education (67,5\%), diet (72,5\%), physical exercise (90\%) in good category, while treatment $(53,8 \%)$ in less category. Discussion: The conclusion of this resaearch are the knowledge about DM management of DM Patients and family at Health Center of Tabanan II are not optimal yet, so it is necessary to develop continuous management education in health services.

Keywords: DM management, knowledge, patient, family

\begin{tabular}{ll}
\hline Alamat Korespondensi : STIKes Wira Medika Bali, Jln. Kecak No 9A Gatsu Timur, \\
Denpasar \\
Email & trisnawika09@gmail.com
\end{tabular}

\section{PENDAHULUAN}

Penyakit kronis pada umumnya adalah Penyakit Tidak Menular (PTM). Penyakit Tidak Menular (PTM) merupakan masalah yang sangat substansial, mengingat pola kejadian sangat menentukan status kesehatan di suatu daerah dan juga keberhasilan peningkatan status kesehatan di suatu negara. Secara global diperkirakan PTM menyebabkan sekitar 60\% kematian dan 43\% kesakitan di seluruh dunia. Salah satu penyakit tidak menular yang menjadi perhatian masyarakat adalah diabetes mellitus (Kemenkes, 2013).

Diabetes mellitus (DM) merupakan ancaman kesehatan masyarakat global, dimana sekitar 90\% dari semua pasien yang menderita DM diseluruh dunia adalah DM tipe 2 (WHO, 2014). Angka kejadian dan prevalensi DM tipe 2 di dunia cenderung meningkat setiap tahun (Sumangkut, Supit, dan Onibala, 2013). Menurut WHO (2011) diabetes mellitus termasuk penyakit yang paling banyak diderita oleh penduduk di seluruh dunia dan merupakan urutan ke empat dari prioritas penelitian nasional untuk penyakit degeneratif. Menurut International of Diabetic Federation (IDF, 2015) jumlah penderita DM di dunia mencapai 387 juta kasus pada tahun 2014. Negara Indonesia sendiri merupakan negara yang memiliki angka kasus penderita DM tertinggi ke-7 di dunia dengan jumlah penderita yaitu sebanyak 8.554.155 orang (IDF, 2013). Data Riset Kesehatan Dasar (Riskesdas) Kementerian Kesehatan RI, pada tahun tahun 2013 kasus DM sudah mencapai angka 9,1 juta jiwa. Jumlah ini terus bertambah dan diprediksi pada tahun 2030 akan mencapai 21,3 juta jiwa. Tingginya kasus DM yang terjadi di Indonesia juga dapat dilihat di Provinsi Bali. Berdasarkan data Dinas Kesehatan Provinsi Bali tahun 2011 jumlah kasus penderita DM mencapai 2280 kasus kemudian tahun 2012 meningkat menjadi 3004 kasus, dimana 52\% jumlah kasus merupakan DM tipe 2 yaitu sebanyak 1469 kasus. Prevalensi penderita DM berdasarkan data Dinas Kesehatan Provinsi Bali tahun 2016 menyatakan bahwa jumlah penderita DM tertinggi berada di Kabupaten Tabanan dengan jumlah kunjungan sebanyak 4995 kunjungan.

Prevalensi Diabetes Melitus yang terus meningkat, secara tidak langsung akan mengakibatkan kesakitan dan kematian akibat komplikasi dari penyakit DM itu sendiri. Akibat dari hiperglikemia dapat terjadi komplikasi metabolik akut seperti Ketoasidosis Diabetic (KAD) dan keadaan hiperglikemi dalam jangka waktu panjang berkontribusi terhadap komplikasi neuropatik. Diabetes mellitus juga berhubungan dengan peningkatan kejadian penyakit makrovaskuler seperti MCI dan stroke (Smeltzer \& Bare, 2013). Beberapa komplikasi lain yang dapat terjadi yakni, gagal ginjal, jantung, nefropati, retinopati, dan ganggren. Hal ini, 
tentu juga akan memberikan efek terhadap kondisi psikologis pasien. Dampak DM terhadap kehidupan dan kesehatan merupakan hal yang perlu dipertimbangkan dan hal-hal kecil secara signifikan dapat berkembang dengan cepat terhadap pasienpasien DM yang dapat menimbulkan kecacatan dengan merusak fungsi tubuh individu dan kualitas hidupnya sehingga memberikan dampak negatif terhadap kualitas dan lama hidup (Hogan et all, 2010).

Cara mencegah terjadinya komplikasi dari DM, diperlukan pengontrolan yang terapeutik dan teratur melalui perubahan gaya hidup pasien DM yang tepat, tegas dan permanen. Pengontrolan DM diantaranya adalah pembatasan diet, peningkatan aktivitas fisik, regimen pengobatan yang tepat, kontrol medis teratur dan pengontrolan metabolik secara teratur melalui pemeriksaan labor. Kepatuhan pasien DM terhadap terapi yang telah diindikasikan dan diresepkan oleh dokter akan memberikan efek terapeutik yang positif (therapeutic compliance). Pasien DM yang mengikuti regimen terapeutik tidak menutup kemungkinan dapat terjadi kegagalan pelaksanaan terapi (noncompliance) seperti keterlambatan terapi, menghentikan terapi, bahkan tidak mengikuti terapi dengan tepat. Pemerintah sendiri tak menutup mata dalam hal pencegahan Diabetes Melitus ini. Terbukti dengan dibentuknya POSBINDU (Pos Pelayanan Terpadu) yang merupakan upaya monitoring atau deteksi dini mengenai faktor risiko PTM di masyarakat. Dimana program ini telah dibentuk sejak 2011 dan pada tahun 2015 telah berkembang hingga 11.027 Posbindu di seluruh Indonesia. Secara umum tindakan pengendalian DM untuk mencegah komplikasi adalah dengan menjaga kadar gula darah agar tetap dalam batas normal, dimana untuk mempertahankan kenormalan kadar gula darah sangatlah sulit bagi kebanyakan pasien. Hal ini disebabkan oleh berbagai faktor, dan salah satu yang terpenting yaitu pasien tidak disiplin dalam melakukan manajemen DM.

Empat pilar manajemen DM menurut Perkumpulan Endokrinologi Indonesia (Perkeni, 2015), diantaranya pengetahuan/edukasi, pola makan seimbang, aktif bergerak, dan mematuhi pengobatan. Diabetes tipe 2 umumnya terjadi akibat pola gaya hidup dan perilaku, terutama pola makan dan aktivitas yang kurang. Pola makan yang tinggi gula ditambah aktivitas kurang menyebabkan seseorang dapat mengidap DM tipe 2. Pengetahuan tentang DM, tata cara minum obat, pola makan, komplikasi, dan tanda kegawat-darutan perlu dimiliki oleh penderita dan keluarga. Sehingga pengetahuan sangatlah penting dalam proses pengendalian Diabetes Melitus.

Menurut Notoatmodjo (2012) pengetahuan merupakan hasil penginderaan manusia, atau hasil tahu seseorang terhadap suatu objek dari indra yang dimilikinya. Pengindraan terjadi melalui pancaindra manusia, yakni indra penglihatan, pendengaran, penciuman, rasa, dan raba dengan sendiri. Pengetahuan penderita tentang diabetes melitus merupakan sarana yang dapat membantu penderita menjalankan penanganan diabetes selama hidupnya sehingga semakin banyak dan semakin baik penderita mengerti tentang penyakitnya semakin mengerti bagaimana harus mengubah perilakunya dan mengapa hal itu diperlukan (Waspadji , 2009). Bila seorang pasien mempunyai pengetahuan tentang risiko terjadinya komplikasi diabetes, maka pasien akan dapat memilih alternatif yang terbaik bagi dirinya dan cenderung memperhatikan hal-hal yang penting tentang perawatan diabetes melitus seperti pasien akan melakukan pengaturan pola makan yang benar, berolah raga secara teratur, mengontrol kadar gula darah dan memelihara lingkungan agar 
terhindar dari benda-benda lain yang dapat menyebabkan luka. Akan tetapi, ketika penderita yang tidak mengindahkan penatalaksanaan tersebut, disinilah peran keluarga sebagai pendukung. Keluarga sebagai sumber bantuan yang terpenting memiliki kemampuan untuk mengubah gaya hidup individu memegang peranan penting tidak hanya dalam fase rehabilitasi melainkan juga dalam fase pencegahan terutama jika dilengkapi dengan pengetahuan yang tepat.

Hasil dari studi pendahuluan yang telah dilakukan dengan wawancara lima penderita DM yang berkunjung ke Puskesmas Tabanan II didapatkan hasil bahwa pasien dan keluarga sudah mendapatkan informasi dari tim kesehatan yang ada di Puskesmas Tabanan II tentang penatalaksanaan DM, namun saat ditanya tiga dari lima pasien hanya menyebutkan tentang diet DM saja dan dua lainnya menyebutkan diet dan olahraga. Keluarga pasien sendiri empat diantaranya hanya menyebutkan diet saja. Alasan peneliti memilih Puskesmas Tabanan II sebagai lokasi penelitian karena di Puskesmas Tabanan II banyak terdapat pasien Diabetes Melitus yang kurang mengetahui tentang gambaran manajemen DM yang tepat dalam mencegah tingkat keparahan penyakit.

Berdasarkan hasil studi pendahuluan, maka peneliti tertarik untuk mengangkat judul "Gambaran Pengetahuan Pasien DM dan Keluarga Tentang Manajemen DM Tipe II".

\section{BAHAN DAN METODE}

Pada penelitian ini, peneliti melakukan penelitian di Wilayah Kerja Puskesmas Tabanan II yaitu Desa Denbantas pada Mei 2017. Rancangan penelitian ini adalah deskriptif kuantitatif dengan pendekatan survey untuk mengetahui gambaran pengetahuan pasien DM dan keluarga tentang manajemen DM tipe 2 dengan menggunakanan alisis univariat. Populasi dalam penelitian adalah Lansia yang berjumlah 100 orang. Jumlah sampel sebanyak 80 orang yang diambil menggunakan purposive sampling. Variabel dalam penelitian ini adalah variabel tunggal yaitu pengetahuan pasien DM dan keluarga tentang manajemen DM tipe 2. Kriteria inklusi dalam penelitian ini meliputi, pada pasien : Pasien DM Tipe 2 di Wilayah Kerja Puskesmas Tabanan II, pasien DM yang tidak mengalami komplikasi akut Diabetes Mellitus. Pada Keluarga : Memiliki hubungan keluarga dengan pasien, keluarga yang tinggal satu rumah dengan pasien atau rumahnya berdekatan dengan pasien, keluarga yang biasa mengurus/membantu kebutuhan pasien. Kriteria eksklusi yaitu, pada pasien : Pasien yang mengalami penurunan kesadaran, pasien yang tidak bersedia menjadi responden. Keluarga : Keluarga yang tidak bersedia menjadi responden.

Data pada penelitian ini didapatkan dari sumber langsung dengan penyebaran kuesioner, dengan kuesioner tentang pengetahuan pasien DM dan keluarga tentang manajemen DM tipe 2 . Analisis data dalam penelitian ini dilakukan secara discriptif denganmenggunakan alat bantu komputer program SPSS 20.0 dan ditampilkan dalam bentuk distribusi frekuensi.

\section{HASIL}

Responden pada penelitian ini adalah pasien DM tipe 2 dan keluarga di Wilayah Kerja Puskesmas Tabanan II sesuai dengan kriteria inklusi \& ekslusi yang berjumlah 80 orang dengan karakteristik : 
Tabel 1 : Distribusi Frekuensi Berdasarkan Umur Pasien

\begin{tabular}{ccc}
\hline Umur & $\begin{array}{c}\text { Frekuensi } \\
(\mathrm{F})\end{array}$ & $\begin{array}{c}\text { Persentase } \\
(\%)\end{array}$ \\
\hline 36-45 tahun & 6 & 7.5 \\
46-55 tahun & 22 & 27.5 \\
56-65Tahun & 27 & 33.8 \\
$>$ 65 tahun & 25 & 31.3 \\
& & \\
Total & 80 & 100 \\
\hline
\end{tabular}

Dari hasil tabel 1, didapatkan bahwa paling banyak responden berada pada rentang umur 56-65 tahun (33,8\%).

Tabel 2 : Distribusi Frekuensi Berdasarkan Umur Keluarga

Umur $\quad$ Frekuensi (F) Persentase (\%)

\begin{tabular}{ccc}
\hline 17-25 tahun & 3 & 3.8 \\
26-35 tahun & 6 & 7.5 \\
$36-45$ tahun & 30 & 37.5 \\
$46-55$ tahun & 24 & 30 \\
56-65 tahun & 12 & 15 \\
$>65$ tahun & 5 & 6.3 \\
Total & 80 & 100 \\
\hline
\end{tabular}

Berdasarkan tabel 4.3 di atas bahwa dari 80 responden terbanyak didominasi oleh responden dalam rentang usia 36-45 tahun yang berjumlah 30 orang (37,5\%). Tabel 3 : Distribusi Frekuensi Responden Berdasarkan Jenis Kelamin Pasien

$$
\text { Jenis Kelamin Frekuensi (F) Persentase (\%) }
$$

$\begin{array}{ccc}\text { Perempuan } & 44 & 55 \\ \text { Laki-laki } & 36 & 45 \\ \text { Total } & 80 & 100\end{array}$

Dari hasil tabel 3,didapatkan bahwa paling banyak responden berjenis kelamin perempuan, yaitu sebanyak 44 orang $(55 \%)$ Keluarga

Tabel 4 : Distribusi Frekuensi Responden Berdasarkan Jenis Kelamin

\begin{tabular}{ccc}
\hline Jenis Kelamin & $\begin{array}{c}\text { Frekuensi } \\
(\mathrm{F})\end{array}$ & $\begin{array}{c}\text { Persentase } \\
(\%)\end{array}$ \\
\hline Perempuan & 37 & 46.3 \\
Laki-laki & 43 & 53.8 \\
Total & 80 & 100 \\
\hline
\end{tabular}


Dari hasil tabel 4,didapatkan bahwa mayoritas responden berjenis kelamin laki-laki yang berjumlah 43 orang $(53,8 \%)$.

Tabel 5 : Distribusi Frekuensi Responden Berdasarkan Pendidikan Terakhir Pasien

\begin{tabular}{ccc}
\hline $\begin{array}{c}\text { Tingkat } \\
\text { Pendidikan }\end{array}$ & $\begin{array}{c}\text { Frekuensi } \\
(\mathrm{F})\end{array}$ & $\begin{array}{c}\text { Persentase } \\
(\%)\end{array}$ \\
\hline Tidak sekolah & 33 & 41.3 \\
SD & 12 & 15 \\
SMP & 4 & 5 \\
SMA & 19 & 23.8 \\
PT & 12 & 15 \\
Total & 80 & 100 \\
\hline
\end{tabular}

Berdasarkan hasil tabel di atas, bahwa dari 80 responden mayoritas responden tidak sekolah yaitu sebanyak 33 orang $(41,3 \%)$.

Tabel 6 :Distribusi Frekuensi Responden Berdasarkan Pendidikan Terakhir Keluarga

\begin{tabular}{ccc}
\hline $\begin{array}{c}\text { Tingkat } \\
\text { Pendidikan }\end{array}$ & $\begin{array}{c}\text { Frekuensi } \\
(\mathrm{F})\end{array}$ & $\begin{array}{c}\text { Persentase } \\
(\%)\end{array}$ \\
\hline Tidak sekolah & 12 & 15 \\
SD & 14 & 17.5 \\
SMP & 3 & 3.8 \\
SMA & 36 & 45 \\
& & \\
PT & 15 & 18.8 \\
Total & 80 & 100 \\
\hline
\end{tabular}

Diperoleh gambaran hasil penelitian dari 80 responden menunjukan pendidikan responden mayoritas yaitu 36 orang (45\%) berpendidikan SMA.

Tabel 7 : Distribusi Frekuensi Responden Berdasarkan Lama Menderita

\begin{tabular}{ccc}
\hline $\begin{array}{c}\text { Lama } \\
\text { Menderita }\end{array}$ & Frekuensi (F) & Persentase (\%) \\
\hline$<4$ tahun & 25 & 31.3 \\
$>4$ tahun & 55 & 68.8 \\
Total & 80 & 100 \\
\hline
\end{tabular}

Dari hasil tabel 7,didapatkan bahwa paling banyak menderita $>4$ tahun yaitu sebanyak 55 orang $(68,8 \%)$. 
Tabel 8 : Distribusi Frekuensi Responden Berdasarkan Sumber Informasi Pasien

\begin{tabular}{ccc}
\hline Sumber & Frekuensi (F) & Persentase (\%) \\
Informasi & & 63.7 \\
\hline Petugas Kes. & 51 & 5 \\
Teman & 4 & 5 \\
Keluarga & 4 & 0 \\
Surat Kabar & 0 & 0 \\
Buku & 0 & \\
& & 0 \\
Majalah & 0 & 2.5 \\
TV & 2 & 0 \\
Radio & 0 & 2.5 \\
Internet & 2 & 21.3 \\
Tidak & 17 & \\
Mendapat Info & & 100 \\
Total & 80 & \\
\hline
\end{tabular}

Diperoleh dari hasil bahwa sebagian besar responden jumlah tertinggi didominasi oleh responden yag menerima informasi dari petugas kesehatan yakni sebanyak 51 orang $(63,8 \%)$.

Tabel 9. Distribusi Frekuensi Responden Berdasarkan Sumber Informasi Keluarga

\begin{tabular}{ccc}
\hline Sumber & Frekuensi (F) & Persentase (\%) \\
Informasi & & \\
\hline Petugas Kes. & 23 & 28.7 \\
Teman & 2 & 10 \\
Keluarga & 8 & 0 \\
Surat Kabar & 0 & 1.3 \\
Buku & 1 & 0 \\
Majalah & 0 & 5 \\
TV & 4 & 0 \\
Radio & 0 & 1.3 \\
Internet & 1 & 51.2 \\
Tidak Mendapat & 41 & \\
Info & & 100 \\
Total & 80 & \\
\hline
\end{tabular}

Dari hasil tabel 9,didapatkan bahwa

Mayorotas responde tidak mendapat informasi yaitu sebanyak 41 orang $(52,2 \%)$. 
Tabel 10 : Distribusi Frekuensi Berdasarkan Pengetahuan Pasien Tentang Manajemen DM Tipe 2

$$
\text { Karakteristik } \quad \text { Frekuensi (F) } \quad \text { Persentase (\%) }
$$

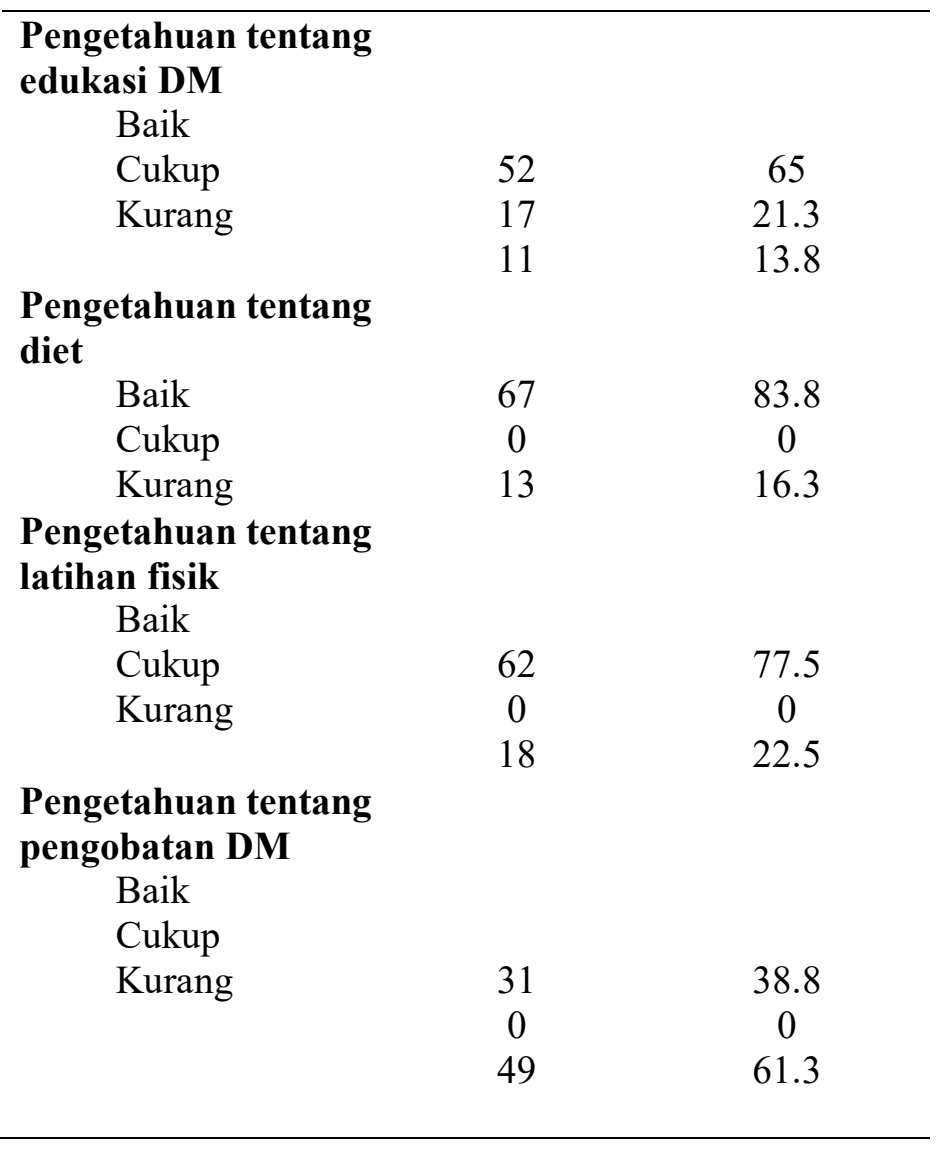

Pada tabel distribusi frekuensi berdasarkan pengetahuan manajemen DM , diperoleh gambaran tentang edukasi DM yaitu sebagian besar berpengetahuan baik yaitu 52 orang $(65 \%)$. Berdasarkan gambaran pengetahuan tentang diet DM menunjukan bahwa mayoritas memiliki pengetahuan baik yaitu 67 orang $(83,8 \%)$. Diperoleh hasil dari distribusi frekuensi pada tabel di atas berdasarkan gambaran pengetahuan tentang latihan fisik didominasi oleh responden berpengetahuan baik yaitu sebanyak 62 orang $(77,5 \%)$. Sedangkan berdasarkan pengetahuan tentang pengobatan, didapatkan hasil bahwa mayoritas responden berpengetahuan kurang tentang pengobatan DM yaitu sebanyak 49 orang $(61,3 \%)$.

Tabel 11 : Distribusi Frekuensi Berdasarkan Pengetahuan Keluarga Tentang Manajemen DM Tipe 2

\begin{tabular}{ccc}
\hline Karakteristik & Frekuensi (F) & Persentase (\%) \\
\hline $\begin{array}{l}\text { Pengetahuan } \\
\text { edukasi DM }\end{array}$ & & \\
Baik & 54 & 67.5 \\
Cukup & 20 & 25
\end{tabular}




\begin{tabular}{ccc}
\hline Kurang & 6 & 7.5 \\
& & \\
& & \\
Pengetahuan \\
tentang diet \\
Baik & & \\
Cukup & 58 & 72.5 \\
$\quad$ Kurang & 0 & 0 \\
Pengetahuan & 22 & 27.5 \\
tentang latihan & & \\
fisik $\quad$ & \\
$\quad$ Baik & & \\
Cukup & 72 & 90 \\
$\quad$ Kurang & 0 & 0 \\
Pengetahuan & 8 & 10 \\
tentang \\
pengobatan DM
\end{tabular}

Pada tabel distribusi frekuensi berdasarkan pengetahuan manajemen DM , mayoritas gambaran tentang edukasi DM yaitu 54 orang $(67,5 \%)$ baik. Pada tabel distribusi frekuensi berdasarkan gambaran pengetahuan tentang diet DM menunjukan bahwa sebagian besar didominasi oleh responden memiliki pengetahuan baik yaitu 58 orang $(72,5 \%)$. Hasil dari distribusi frekuensi pada tabel di atas berdasarkan gambaran pengetahuan tentang latihan fisik yaitu sebagian besar berpengetahuan baik yakni sebanyak 72 orang $(90 \%)$. Sementara, Berdasarkan pengetahuan tentang pengobatan, didapatkan hasil bahwa mayoritas dalam katagori kurang yakni sebanyak 43 orang $(53,8 \%)$.

\section{PEMBAHASAN}

\section{Pembahasan hasil penelitian berdasarkan data demografi}

\section{Umur}

1. Pasien

Prevalensi penderita DM pada penelitian ini rata-rata terjadi pada rentang usia 56-65 tahun. Penelitian ini didukung oleh penelitian yang dilakukan Febty (2014) yang menyatakan bahwa mayoritas karakteristik responden berdasarkan umur yaitu usia $>45$ tahun berjumlah 51 orang (87,9\%). Tandra (2008) mengatakan bahwa risiko terkena diabetes akan meningkat dengan bertambahnya usia terutama diatas 40 tahun, dimana pada usia ini atau yang kurang gerak badan, massa otot berkurang sehingga pemakaian glukosa berkurang dan gula darah pun akan meningkat. Berdasarkan hasil penelitian di atas, dapat diketahui bahwa penyakit 
DM cenderung dialami oleh orang yang berusia $>40$ tahun, akibat dari terjadinya penurunan fungsi organ tubuh.

\section{Keluarga}

Pada penelitian ini urutan tiga terbanyak didominasi oleh responden pada rentang usia 36-45 tahun yang berjumlah 30 orang, 46-55 sebanyak 24 orang, dan rentang usia 56-65 berjumlah 12 orang dari 80 responden. Hasil penelitian ini sejalan dengan penelitian yang dilakukan oleh Nugraheni (2016) yang mengungkapkan bahwa responden terbanyak yaitu dengan rentang usia 30-60 tahun. Mayoritas pendukung pada penelitian ini adalah pasangan yang rata-rata usianya hampir sama dengan penderita. Usia ini menjadi responden terbanyak karena pada rentang usia ini sudah dianggap mampu untuk bertanggung jawab menjaga dan mengurus anggota keluarga.

\section{Jenis kelamin}

\section{Pasien}

Berdasarkan hasil penelitian dapat diketahui bahwa dari 80 responden terdapat 44 orang $(55 \%)$ berjenis kelamin perempuan dan sebanyak 36 orang $(45 \%)$ berjenis kelamin laki-laki, dimana prevalensi penderita DM terbanyak terjadi pada perempuan. Hasil penelitian ini mendapat hasil yang sama dengan penelitian yang dilakukan oleh Febty (2014) dimana hasil yang didapatkan yaitu responden perempuan berjumlah 43 orang $(74,1 \%)$ dari 58 responden. Menurut Riskesdas (2013) prevalensi perempuan lebih banyak daripada laki-laki, hal ini dikarenakan beberapa faktor risiko seperti obesitas, kurang aktivitas, usia dan riwayat DM saat hamil sehingga tingginya kejadian DM pada perempuan (Radi, 2007). Penelitian ini tidak sejalan dengan Ardita (2014) yang mengatakan bahwa DM lebih banyak diderita oleh lak-laki yaitu sebesar $60,6 \%$.

2. Keluarga

Hasil penelitian yang telah dilakukan bahwa sebanyak 37 orang (46.3\%) berjenis kelamin perempuan dan sebanyak 43 orang $(53.8 \%)$ berjenis kelamin lakilaki dari 80 responden. Hal ini dikarenakan mayoritas penderita DM adalah perempuan sehingga pasangan yang menjadi support system adalah laki-laki. Hasil penelitian ini sejalan dengan penelitian Amelia, dkk (2014) yang menyatakan bahwa mayoritas penderita DM adalah perempuan, yaitu sebesar 56,6\%. Wanita lebih berisiko terkena DM karena secara fisik wanita memiliki peluang peningkatan indeks masa tubuh yang lebih besar. Sindroma siklus menstruasi, pasca-menopouse yang membuat distribusi lemak tubuh menjadi mudah terakumulasi akibat proses hormonal tersebut, sehingga wanita berisiko menderita DM Tipe 2 ( Damayanti dalam Irawan, 2010).

\section{Pendidikan terakhir}

\section{Pasien}

Berdasarkan hasil penelitian yang telah dilakukan didapatkan bahwa dari 80 responden terdapat 33 orang $(41,3 \%)$ yang tidak mengenyam pendidikan, 12 orang $(15 \%)$ hanya sampai tingkat SD, 4 orang (5\%) SMP, 19 orang $(23,8 \%)$ berpendidikan tingkat SMA, dan 12 orang (15\%) perguruan tinggi. Dari penelitian tersebut mayoritas responden berdasarkan tingkat pendidikan di wilayah Puskesmas Tabanan II yaitu tidak sekolah, namun dapat disimpulkan bahwa sebagian besar responden berpendidikan mulai dari tingkat SD, SMP, SMA, dan 
Perguruan Tinggi yang total berjumlah 47 responden. Menurut Notoatmodjo (2010) seseorang yang memiliki pendidikan lebih tinggi akan mempunyai pengetahuan yang lebih luas dibandingkan seseorang yang tingkat pendidikannya lebih rendah. Dimana pendidikan merupakan dasar utama untuk keberhasilan dalam pengobatan sesesorang (Sutanegoro dalam Gultom, 2012).

\section{Keluarga}

Dari gambaran hasil penelitian berdasarkan pendidikan terakhir, dari 80 responden menunjukan pendidikan responden yaitu 12 orang (15\%) tidak sekolah, 14 orang $(17,5 \%)$ pendidikannya SD, 3 orang $(3,8 \%)$ pendidikannya SMP, 36 orang (45\%) berpendidikan SMA, dan 15 orang $(18,8 \%)$ mengenyam hingga ke perguruan tinggi. Pada penelitian ini didominasi oleh responden dengan pendidikan SMA, hal ini berdasarkan kondisi yang ditemukan oleh peneliti di lapangan ketika melakukan penelitian dengan kunjungan rumah. Hasil penelitian ini sejalan dengan penelitian oleh Nugraheni (2016) dimana sebagian besar tingkat pendidikan responden yaitu SMA karena lokasi penelitian yang memudahkan responden untuk mengakses fasilitas pendidikan. Menurut Gloria (2013) sebagian besar responden dengan usia $>40$ tahun memiliki tingkat pendidikan SMA. Pendidikan terakhir responden sudah tergolong dalam pendidikan menengah, dikarenakan lokasi penelitian berada di wilayah perkotaan yang mudah untuk mengakses berbagai fasilitas pendidikan.

\section{Lama menderita}

Penelitian yang telah dilakukan berdasarkan karakteristik responden, diperoleh gambaran yang menderita $\mathrm{DM}<4$ tahun sebanyak 25 orang $(31,3 \%)$, dan yang menderita $\mathrm{DM}>4$ tahun sebanyak 55 orang $(68,8 \%)$. Dimana mayoritas responden menderita DM Tipe 2 yaitu $>4$ tahun. Penelitian ini sejalan dengan penelitian yang dilakukan oleh Gultom (2012) bahwa penderita DM Tipe 2 sebagian besar menderita lebih dari 4 tahun dan penelitian oleh Febty (2014) yaitu rata-rata menderita selama 5 tahun. Waspadji (2009) mengatakan bahwa semakin lama pasien menderita DM dengan kondisi hiperglikemi, maka semakin tinggi kemungkinan terjadinya komplikasi kronik. Penelitian tidak sejalan dengan teori tersebut. Berdasarkan hasil penelitian, bahwa mayoritas responden menderita $>4$ tahun namun peneliti tidak menemukan responden dengan komplikasi kronik, sehingga lamanya seseorang menderita DM belum tentu mengalami komplikasi dikarenakan gaya hidup yang baik dan teratur.

\section{Sumber informasi}

\section{Pasien}

Diperoleh dari hasil penelitian bahwa sebanyak 51 orang $(63,8 \%)$ memperoleh sumber informasi dari petugas kesehatan, 4 orang $(5 \%)$ dari temannya, 4 orang $(5 \%)$ dari keluarga, tidak ada yang memperoleh informasi dari surat kabar, buku, majalah, dan radio $(0 \%), 2$ orang $(2,5 \%)$ dari televisi, 2 orang $(2,5 \%)$ dari internet, sementara 17 orang $(21,3 \%)$ tidak memperoleh informasi. Mayoritas dari penelitian ini yaitu responden memperoleh informasi dari petugas kesehatan mengenai Manajemen DM Tipe 2. Hasil penelitian ini sejalan dengan penelitian yang dilakukan oleh Susanti dan Tri (2013) dimana sebagian besar respondennya sering mendapat paparan informasi. Peneltian ini juga didukung oleh teori Notoatmodjo (2010) yang mengatakan bahwa pengetahuan seseorang salah satunya 
dipengaruhi oleh sumber informasi yang didapatkan. Sebagai sarana komunikasi atau informasi, sumber informasi mempunyai pengaruh besar terhadap penegetahuan karena semakin banyak informasi yang diperoleh, semakin luas pula penegetahuan seseorang.

2. Keluarga

Berdasakan hasil penelitian didapatkan bahwa sebanyak 23 orang $(28,7 \%)$ telah memperoleh informasi dari petugas kesehatan, 2 orang $(2,5 \%)$ dari teman, 8 orang $(10 \%)$ dari keluarga, surat kabar, majalah, dan radio tidak ada $(0 \%)$, informasi dari buku hanya 1 orang $(1,3 \%)$, dari TV 4 orang $(5 \%)$, dari internet hanya 1 orang $(1,3 \%)$, serta sebanyak 41 orang $(51,2 \%)$ tidak mendapat informasi. Hasil penellitian ini didominasi oleh responden yang belum pernah mendapat informasi mengenai Manajemen DM Tipe 2, hal ini karena biasanya hanya penderita DM yang mendapat penyuluhan kesehatan sementara keluarga tidak diikut sertakan. Hasil penelitian ini sejalan dengan penelitian yang dilakukan oleh Nugraheni (2016) dimana responden dalam penelitiannya sebagian besar tidak mendapat informasi mengenai DM. Informasi mengenai masalah kesehatan dan program pelayanan kesehatan masyarakat masih rendah. Paparan informasi dapat berkaitan dengan letak demografi responden, dimana responden yang berada di desa lebih sulit untuk memperoleh dan mengakses informasi yang berkaitan dengan kesehatannya (Depkes, 2015).

\section{Pembahasan hasil penelitian berdasarkan gambaran pengetahuan pasien dan keluarga tentang Manajemen DM Tipe 2}

\section{Edukasi}

Hasil penelitian berdasarkan pengetahuan pasien tentang edukasi DM yaitu 52 orang $(65 \%)$ berpengetahuan baik, 17 orang $(21,3 \%)$ berpengetahuan cukup, dan 11 orang $(13,8 \%)$ berpengetahuan kurang. Berdasarkan pengetahuan manajemen DM , diperoleh gambaran keluarga tentang edukasi DM yaitu 54 orang $(67,5 \%)$ baik, 20 orang $(25 \%)$ berpengetahuan cukup, dan 6 orang $(7,5 \%)$ berpengetahuan kurang. Dari hasil penelitian tersebut sebagian besar responden baik pasien maupun keluarga pengetahuan Manajemen DM tentang edukasinya dinilai baik. Hasil penelitian ini sejalan dengan penelitian yang dilakukan oleh Febty (2014) yaitu responden yang memiliki pengetahuan baik sebesar 50,0\%, responden dengan pengetahuan cukup sebesar 43,1\%, dan yang memiliki pengetahuan kurang yaitu sebanyak $6,9 \%$. Sementara mendapat hasil yang berbeda dengan penelitian oleh Gultom (2012) yang menyatakan bahwa sebagian besar responden pengetahuan edukasinya rendah yaitu sebesar $47 \%$.

Edukasi dalam manajemen DM sangat penting, dimana tujuan utama edukasi adalah memberikan pengetahuan kepada pasien maupun keluarga tentang perubahan perilaku hidup sehat dengan meningkatkan pengetahuan dan keterampilan dalam melaksanakan perawatan mandiri. Hal ini memerlukan penilaian, perencanaan, implementasi, dokumentasi, dan evaluasi (Perkeni, 2015). Manfaat edukasi sendiri yaitu agar hidup lebih lama dan berkualitas, komplikasi yang minimal, beban keuangan yang berkurang dan hidup mandiri (Soegondo, 2009). Edukasi yang diberikan adalah pemahaman tentang perjalanan penyakit, pentingnya penegendalian penyakit, olahraga dan diet teratur, serta intervensi obat. 
Ditinjau dari karakteristik responden (pasien) menurut umur pasien, dapat diketahui bahwa responden yang dalam katagori baik mayoritas dalam rentang usia 56-65 tahun yang berjumlah 17 orang $(21,3 \%)$. Berdasarkan karakteristik umur keluarga, dapat diketahui bahwa responden yang dalam katagori baik mayoritas dalam rentang usia 36-45 tahun yang berjumlah 24 orang (30\%). Tingkat pengetahuan yang bervariasi salah satunya dipengaruhi oleh karakteristik umur, persepsi, motivasi oleh individu tersebut. Pada penelitian Nuryani (2012) mengatakan umur merupakan salah satu sifat karakteristik dari seseorang yang mempunyai hubungan dengan tingkat keterpaparan, besarnya risiko serta sifat resistensi. Pada hasil penelitian didapatkan kelompok umur yang memiliki pengetahuan baik yaitu rentang 56-65 tahun pada pasien, dan rentang usia 36-45 tahun pada keluarga. Hal ini terjadi karena semakin tua umur semakin matang perkembangan mentalnya dan berpengaruh pada pengetahuan yang diperolehnya. Akan tetapi, menjelang lansia kemampuan mengingat dan menerima sesuatu pengetahuan akan berkurang.

Karakteristik berdasarkan tingkat pendidikan, mayoritas responden (pasien) yang memiliki pengetahuan baik yaitu SMA yang berjumlah 16 orang (20\%). Sedangkan karakteristik berdasarkan tingkat pendidikan keluarga, mayoritas responden yang memiliki pengetahuan baik yaitu SMA yang berjumlah 29 orang (36,3\%). Hal ini didukung dengan hasil penelitian yang dilakukan Nuryani (2012) yang mendapat nilai pengetahuan meningkat seiring dengan tingkat pendidikan. Tingkat Pendidikan merupakan indikator bahwa seseorang telah menempuh pendidikan formal dibidang tertentu, semakin tinggi Pendidikan seseorang, semakin baik pengetahuannya Wawan dan Dewi (2010).

Menurut karakteristik lama menderita DM, diketahui bahwa sebagian besar responden yang berpengetahuan baik yaitu menderita selama $>4$ tahun yang berjumlah 36 orang (45\%). Lamanya seseorang menderita mempengaruhi seseorang dalam melakukan manajemen DM dibandingkan dengan seseorang yang baru menderita. Dimana seseorang yang telah lama menderita DM mempunyai pengalaman yang lebih banyak Ermawati (2011). Hal ini disebabkan karena pengalaman merupakan salah satu faktor yang mempengaruhi tingkat pengetahuan sebagaimana yang dinyatakan Notoatmodjo (2010). Pada hasil penelitian bahwa mayoritas responden yang berpengetahuan baik adalah responden dengan lama menderita selama $>4$ tahun. Dengan demikian dapat diketahui bahwa seseorang yang lebih lama menderita penyakit DM akan mempunyai pengetahuan dan sikap yang cenderung lebih baik dibandingkan dengan seseorang yang baru menderita DM.

Berdasarkan karakteristik sumber informasi diketahui bahwa responden (pasien) yang dalam katagori baik mayoritas mendapat informasi dari petugas kesehatan yaitu sebanyak 36 orang (45\%). Menurut karakteristik sumber informasi diketahui bahwa responden (keluarga) yang dalam katagori baik mayoritas tidak mendapat informasi yaitu sebanyak 21 orang (26,5\%). Wawan dan Dewi (2010) mengatakan adanya informasi dapat membantu mempercepat seseorang untuk memperoleh pengetahuan baru dan semakin banyak mendapatkan informasi maka pengetahuan akan semakin luas. Hasil penelitian ini sejalan dengan penelitian yang dilakukan oleh Susanti dan Tri (2013) dimana sebagian besar respondennya sering mendapat paparan informasi sehingga pengetahuannya terhadap pencegahan penyakit DM termasuk dalam katagori baik. Akan tetapi terdapat juga perbedaan 
antara penelitian ini dengan penelitian yang dilakukan oleh Susanti dan Tri yakni; dalam penelitian ini peneliti menemukan bahwa anggota keluarga pasien yang tidak mendapatkan informasi mengenai manajemen diri DM dari tenaga medis ternyata sudah memiliki pengetahuan dasar mengenai edukasi manajemen DM, sehingga mayoritas berada dalam katagori baik.

Hasil penelitian yang diperoleh menunjukkan bahwa mayoritas penderita DM dan keluarga memiliki pengelolaan manajemen DM (edukasi) yang baik. Berdasarkan hasil penelitian di wilayah kerja Puskesmas Tabanan II didapatkan pengetahuan edukasi tertinggi yaitu pada butir pernyataan nomor 8 baik oleh pasien maupun keluarga mengenai pengetahuan tentang pemeriksaan kadar gula berkala atau teratur. Sedangkan butir pernyataan terendah yaitu butir nomor 9 oleh pasien tentang penggunaan kaos kaki dan butir nomor 5 oleh keluarga yaitu bahwa diabetes tidak mengakibatkan gangguan pendengaran.

\section{Diet}

Berdasarkan hasil penelitian gambaran pengetahuan pasien tentang diet DM menunjukan bahwa 67 orang $(83,8 \%)$ memiliki pengetahuan baik tentang diet, berpengetahuan cukup tidak ada ( $0 \%)$, dan berpengetahuan kurang yaitu 13 orang $(16,3 \%)$. Sementara gambaran pengetahuan keluarga tentang diet DM menunjukan bahwa 58 orang $(72,5 \%)$ memiliki pengetahuan baik tentang diet, berpengetahuan cukup tidak ada $(0 \%)$, dan berpengetahuan kurang yaitu 22 orang $(27,5 \%)$. Jadi, pada penelitian ini didapatkan hasil bahwa sebagian besar responden yaitu pasien dan keluarga keduanya memiliki pengetahuan baik tentang diet DM. penelitian ini mendapat hasil yang berbeda dengan penelitian yang dilakukan oleh Sonyo (2016) dan Nugraheni (2016) yang menyatakan bahwa sebagian respondennya memiliki pengetahuan kurang tentang diet DM.

Diet DM sangat dianjurkan untuk mempertahankan kadar glukosa darah agar dalam batas normal, mencapi kadar serum lipid yang optimal, dan menangani komplikasi akut serta meningkatkan kesehatan secara keseluruhan (Sukardji, 2009). Prinsip anjuran asupan makanan pada penderita DM tidak jauh berbeda dengan masyarakat pada umumnya, yaitu makanan yang seimbang dan sesuai dengan kebutuhan kalori dan zat gizi masing-masing individu. Pada penyandang DM perlu diberikan penekanan menegnai pentingnya keteraturan waktu makan, jenis dan jumlah kandungan kalori, terutama untuk penderita DM yang mengkonsumsi obat yang meningkatkan sekresi insulin. Adapun standar yang dianjurkan adalah makanan yang mengandung komposisi karbohidrat, protein, lemak, natrium, dan serat yang sesuai kecukupan gizi (Perkeni, 2015).

Ditinjau berdasarkan karakteristik umur pasien, dapat diketahui bahwa responden yang dalam katagori baik mayoritas dalam rentang usia $>65$ tahun yang berjumlah 21 orang $(26,3 \%)$. Berdasarkan karakteristik umur keluarga dapat diketahui bahwa responden yang dalam katagori baik mayoritas dalam rentang usia 36-45 tahun yang berjumlah 26 orang $(32,5 \%)$. Hasil penelitian ini berdasarkan karakteristik umur responden mendapat hasil yang sama dengan penelitian oleh Nasihah dan Sifia (2013) yang menyatakan bahwa semakin cukup umur seseorang maka tingkat pengetahuan dan kematangan dalam berfikir akan semakin baik. Penelitian ini juga didukung oleh teori Wawan dan Dewi (2010) yang mengatakan bahwa semakin cukup umur, tingkat kematangan dan kekuatan seseorang akan 
lebih matang dalam berfikir dan bekerja. Penyampaian informasi yang baik yaitu pada masa kedewasaan karena masa kedewasaan merupakan masa dimana terjadi perkembangan intelegensia, kematangan mental, kepribadian, pola pikir dan perilaku sosial. Sehingga dari informasi yang didapat akan membentuk sebuah pengetahuan dan sikap dilihat dari respons setelah informasi diterima. Hal ini tidak mendapat hasil yang sama dengan penelitian Nugraheni (2016) yang menyatakan bahwa pada usia dewasa madya yaitu rentang 30-60 tahun mulai terjadi penurunan fungsi dan cara berfikir seseorang.

Dilihat berdasarkan karakteristik jenis kelamin pasien, diketahui bahwa mayoritas responden dalam katagori baik yaitu perempuan yang berjumlah 36 orang $(45 \%)$. Berdasarkan karakteristik jenis kelamin keluarga, diketahui bahwa mayoritas responden dalam katagori baik yaitu laki-laki yang berjumlah 31 orang (38,8\%). Hasil penelitian berdasarkan jenis kelamin pasien mendapat hasil yang sama dengan penelitian oleh Kristianto, Anton, Anthony, Caroline, Astari, Farha, dan Budi (2012) yang menyatakan bahwa tingkat pengetahuan perempuan tentang masalah kesehatan mayoritas baik, hal ini berkaitan dengan kesadaran perempuan akan pentingnya masalah kesehatan. Penelitian ini mendapat hasil yang berbeda dengan penlitian yang dilakukan oleh Senuk, Wenny, dan Franly (2013) dimana $71 \%$ pengetahuan responden perempuan dalam katagori kurang baik.

Karakteristik menurut tingkat pendidikan pasien, mayoritas responden yang memiliki pengetahuan baik yaitu responden yang tidak sekolah dimana berjumlah 24 orang $(30 \%)$. Karakteristik berdasarkan tingkat pendidikan terakhir keluarga, mayoritas responden yang memiliki pengetahuan baik yaitu tingkat pendidikan SMA dimana berjumlah 28 orang (35\%). Juwaningtyas (2014) menyatakan bahwa semakin tinggi pendidikan seseorang maka semakin mendorong keingintahuannya dalam suatu penyakit sehingga dapat mengambil tindakan secepatnya. Penelitian yag dilakukan Sutrisno (2011) mengungkapkan bahwa pendidikan merupakan salah satu faktor yang dapat mempengaruhi pengetahuan seseorang, semakin tinggi pendidikan seseorang, maka akan semakin mudah pula dalam menerima informasi yang pada akhirnya makin banyak pengetahuan yang mereka miliki. Dari hasil penelitian pada keluarga didapatkan mayoritas yang berpengetahuan kurang justru yang berpendidikan menengah dan perguruan tinggi. Pengetahuan responden kurang terutama mengenai cara memasak makanan untuk menurunkan kadar gula darah. Pendidikan responden tergolong menengah bahkan tinggi, tetapi pengetahuannya dalam katagori kurang, dikarenakan masih ada faktor lain yang mempengaruhi pengetahuan tersebut.

Ditinjau menurut karakteristik lama menderita DM, diketahui bahwa sebagian besar responden yang berpengetahuan baik yaitu menderita selama $>4$ tahun yang berjumlah 45 orang $(56,3 \%)$. Pasien yang terkena diabetes dalam kurun waktu lebih lama akan lebih sering terpapar dengan fasilitas kesehatan dan tenaga kesehatan yang memberikan intruksi terkait manajemen DM dan menjadi waspada terhadap komplikasi dan tidak terkontrolnya kadar gula darah (Abebaw dkk, 2016). Penelitian yang dilakukan Phitri dan Widyaningsih (2013) menyatakan bahwa seseorang yang sudah lama menderita DM akan mempunyai pengetahuan dan pengalaman sehingga mampu merespon terhadap penyakitnya dengan rajin melakukan penatalaksanaan.

Berdasarkan karakteristik sumber informasi yang diperoleh pasien, diketahui bahwa responden yang dalam katagori baik mayoritas mendapat 
informasi dari petugas kesehatan yaitu sebanyak 44 orang (55\%). Menurut karakteristik sumber informasi diketahui bahwa keluarga yang dalam katagori baik mayoritas tidak mendapat informasi yaitu sebanyak 27 orang $(33,8 \%)$. Hasil penelitian terhadap keluarga memiliki hasil yang sama dengan Lestari (2012) dimana mayoritas responden dalam penelitiannya kurang dalam mendapat paparan informasi kesehatan. Rasajati, Bambang, dan Dina (2015) dalam penelitiannya menyatakan bahwa paparan informasi sangat sangat mempengaruhi pengetahuan seseorang, semakin sering seseorang mendapat paparan informasi maka semakin baik pengetahuannya. Penelitian oleh Rasajati dkk ini sejalan dengan hasil pada penelitian terhadap pasien, dimana sebagian besar responden yang berpengetahuan baik telah medapat paparan informasi dari petugas kesehatan.

Hasil penelitian yang diperoleh menunjukan bahwa mayoritas penderita DM dan keluarga memiliki pengelolaan manajemen DM (diet) yang baik. Pengetahuan responden baik pada konsep umum diet pasien DM, karena responden tahu jika pasien DM harus menghindari konsumsi rokok dan alkohol. Sedangkan sedangkan minoritas responden yang memiliki pengetahuan kurang dikarenakan ketidaktahuannya mengenai cara memasak makanan untuk menurunkan kadar gula darah.

\section{Latihan fisik}

Berdasarkan gambaran pengetahuan tentang latihan fisik yaitu sebanyak 62 orang $(77,5 \%)$ memiliki pengetahuan baik, $(0 \%)$ berpengetahuan cukup, dan 18 orang $(22,5 \%)$ memiliki pengetahuan kurang terhadap latihan fisik. Hasil dari distribusi frekuensi berdasarkan gambaran pengetahuan keluarga tentang latihan fisik yaitu sebanyak 72 orang (90\%) memiliki pengetahuan baik, (0\%) berpengetahuan cukup, dan 8 orang (10\%) memiliki pengetahuan kurang terhadap latihan fisik. Hal tersebut menandakan pada penelitian ini sebagian besar responden memiliki pengetahuan baik mengenai latihan fisik. Hasil penelitian ini mendapat hasil yang berbeda dengan penelitian oleh Warsito (2016) dan Gultom (2012) dimana mayoritas respondennya memiliki pengetahuan cukup tentang latihan fisik.

Latihan fisik dianjurkan untuk dilakukan secara teratur yaitu 3-4 kali dalam seminggu selama kurang lebih 30 menit (Soegondo, 2009). Latihan jasmani ini disesuaikan dengan kemampuan dan kondisi penyakit penyerta dan maksimal denyut nadi 220x/menit. Latihan jasmani yang aman adalah jalan kaki biasa selama 30 menit, olahraga sedang berjalan cepat selama 20 menit, dan olahraga berat misalnya jogging. Olahraga aman seperti misalnya berjalan, bersepeda, berenang, dan senam. Prinsip latihan jasmani pada pasien penderita DM adalah frekwensi, intensitas, durasi, dan jenis latihan.

Berdasarkan karakteristik umur pada pasien, dapat diketahui bahwa responden yang dalam katagori baik mayoritas dalam rentang usia $>65$ tahun yang berjumlah 20 orang $(25 \%)$. Hasil penelitian ini berdasarkan karakteristik umur responden mendapat hasil yang sama dengan penelitian oleh Nasihah dan Sifia (2013) yang menyatakan bahwa semakin cukup umur seseorang maka tingkat pengetahuan dan kematangan dalam berfikir akan semakin baik. Penelitian ini juga didukung oleh teori Wawan dan Dewi (2010) yang mengatakan bahwa semakin cukup umur, tingkat kematangan dan kekuatan seseorang akan lebih matang dalam berfikir dan bekerja. Penyampaian informasi yang baik yaitu pada masa kedewasaan karena masa kedewasaan merupakan masa dimana terjadi 
perkembangan intelegensia, kematangan mental, kepribadian, pola pikir dan perilaku sosial. Sehingga dari informasi yang didapat akan membentuk sebuah pengetahuan dan sikap dilihat dari respons setelah informasi diterima. Hal ini tidak mendapat hasil yang sama dengan penelitian Nugraheni (2016) yang menyatakan bahwa pada usia dewasa madya yaitu rentang 30-60 tahun mulai terjadi penurunan fungsi dan cara berfikir seseorang. Berdasarkan karakteristik umur keluarga, dapat diketahui bahwa responden yang dalam katagori baik mayoritas dalam rentang usia 36-45 tahun yang berjumlah 30 orang $(37,5 \%)$. Hasil penelitian ini sejalan dengan penelitian yang dilakukan oleh Warsito (2016) bahwa pada usia dewasa madya memiliki pengetahuan yang baik mengenai latihan fisik. Hal ini terjadi karena semakin tua umur semakin matang perkembangan mentalnya dan berpengaruh pada pengetahuan yang diperolehnya. Akan tetapi, menjelang lansia kemampuan mengingat dan menerima sesuatu pengetahuan akan berkurang.

Berdasarkan karakteristik jenis kelamin pasien, diketahui bahwa mayoritas responden dalam katagori baik yaitu perempuan yang berjumlah 32 orang (40\%). Dalam penelitian Kristianto (2012) yang menyatakan bahwa tingkat pengetahuan perempuan tentang masalah kesehatan mayoritas baik. Hal ini mendapat hasil yang berbeda dengan penelitian Irawan (2010) yang mengatakan bahwa pengetahuan masyarakat di negara berkembang terutama perempuan lebih rendah berkaitan dengan hambatan dalam mengakses informasi. Berdasarkan karakteristik jenis kelamin keluarga, diketahui bahwa mayoritas responden dalam katagori baik yaitu laki-laki yang berjumlah 38 orang (47,5\%). Hal ini dikarenakan laki-laki dianggap lebih gampang dalam mengakses sumber informasi termasuk informasi mengenai kesehatan itu sendiri.

Karakteristik berdasarkan tingkat pendidikan, mayoritas responden yang memiliki pengetahuan baik yaitu responden yang tidak sekolah dimana berjumlah 20 orang $(25 \%)$. Rendahnya tingkat pendidikan dari pengamatan peneliti, tidak mempengaruhi tingkat pengetahuan responden. Karena tidak hanya faktor Pendidikan yang mempengaruhi pengetahuan, namun juga dipengaruhi oleh beberapa faktor lainnya. Menurut Wawan dan Dewi (2010) bahwa pengetahuan dipengaruhi oleh beberapa faktor, diantaranya umur, Pendidikan, pekerjaan, dan informasi yang diperoleh responden. Karakteristik berdasarkan tingkat pendidikan terakhir keluarga, mayoritas responden yang memiliki pengetahuan baik yaitu responden dengan tingkat pendidikan SMA dimana berjumlah 33 orang $(41,3 \%)$. Juwaningtyas (2014) menyatakan bahwa semakin tinggi pendidikan seseorang maka semakin mendorong keingintahuannya dalam suatu penyakit sehingga dapat mengambil tindakan secepatnya. Penelitian yag dilakukan Sutrisno (2011) mengungkapkan bahwa pendidikan merupakan salah satu faktor yang dapat mempengaruhi pengetahuan seseorang, semakin tinggi pendidikan seseorang, maka akan semakin mudah pula dalam menerima informasi yang pada akhirnya makin banyak pengetahuan yang mereka miliki.

Menurut karakteristik lama menderita DM, diketahui bahwa sebagian besar responden yang berpengetahuan baik yaitu menderita selama $>4$ tahun yang berjumlah 43 orang $(53,8 \%)$. Pasien yang terkena diabetes dalam kurun waktu lebih lama akan lebih sering terpapar dengan falitas kesehatan dan tenaga kesehatan yang memberikan intruksi terkait manajemen DM dan menjadi waspada terhadap komplikasi dan tidak terkontrolnya kadar gula darah (Abebaw dkk, 2016). Penelitian yang dilakukan Phitri dan Widyaningsih (2013) menyatakan bahwa 
seseorang yan sudah lama menderita DM akan mempunyai pengetahuan dan pengalaman sehingga mampu merespon terhadap penyakitnya dengan rajin melakukan penatalaksanaan. Seseorang yang lama menderita DM dapat mempelajari perilaku berdasarkan pengalaman yang diperolehnya selama menjalani penyakit tersebut sehingga responden dapat memahami tentang hal-hal terbaik yang perlu dilakukannya tentang latihan fisik untuk penyakit DM.

Ditinjau berdasarkan karakteristik sumber informasi diketahui bahwa responden yang dalam katagori baik mayoritas mendapat informasi dari petugas kesehatan yaitu sebanyak 40 orang (50\%). Menurut karakteristik sumber informasi keluarga diketahui bahwa responden yang dalam katagori baik mayoritas tidak mendapat informasi yaitu sebanyak 34 orang (42,5\%). Hasil Penelitian terhadap pasien diatas sejalan dengan penelitian yang dilakukan Paulus (2012) yang menyatakan bahwa sebagian besar respondennya yang memiliki pengetahuan baik telah mendapat informasi dari tim kesehatan. Berdasarkan teori Notoatmodjo (2010) yang menyatakan bahwa sumber informasi mempunyai pengaruh besar terhadap pembentukan opini dan kepercayaan orang, dimana seseorang yang mempunyai sumber informasi lebih banyak akan mempunyai pengetahuan yang lebih luas. Berbeda halnya dengan hasil penelitian terhadap keluarga, dimana sebagian besar responden yang berpengetahuan baik tidak mendapat informasi dikarenakan saat penyuluhan keluarga tidak dilibatkan/diikut sertakan dalam pemberian informasi tersebut. Akan tetapi pengetahuan baik tersebut ditunjang dari latar belakang pendidikan responden yang mayoritas berpendidikan menengah dan perguruan tinggi.

Hasil penelitian yang diperoleh menunjukan bahwa mayoritas penderita DM dan keluarga memiliki pengelolaan manajemen DM (latihan fisik) yang baik. Pengetahuan responden baik karena responden tahu jika olahraga rutin sangat bagus untuk membantu mengontrol kadar gula darah. Sedangkan sedangkan minoritas responden yang memiliki pengetahuan kurang dikarenakan ketidaktahuannya jika olahraga yang baik adalah kurang lebih 30 menit.

\section{Pengobatan}

Hasil penelitian yang diperoleh bahwa sebanyak 31 orang $(38,8 \%)$ berpengetaahuan baik tentang pengobatan DM, berpengetahuan cukup tidak ada $(0 \%)$, dan sebanyak 49 orang $(61,3 \%)$ berpengetahuan kurang tentang pengobatan DM. Berdasarkan tabel distribusi frekuensi Manajemen DM tentang pengobatan DM, didapatkan hasil bahwa sebanyak 37 orang $(46,3 \%)$ berpengetahuan baik tentang pengobatan DM, berpengetahuan cukup tidak ada (0\%), dan sebanyak 43 orang $(53,8 \%)$ berpengetahuan kurang tentang pengobatan DM. Berdasarkan hasil tersebut didapatkan sebagian besar responden berpengetahuan kurang tentang pengobatan DM. Penelitian ini mendapat hasil yang sama dengan Gultom (2012) yang menyatakan sebagian besar respondennya memiliki pengetahuan rendah tentang obat-obatan DM.

Terapi obat diberikan bersama dengan pengaturan makan dan latihan jasmani (gaya hidup sehat). Obat yang diberikan yaitu terapi obat hipoglikemik oral (OHO) atau dengan injeksi insulin yang dapat membantu penurunan gula dalam darah pada penderita diabetes. Pemberian terapi insulin dimulai apabila obat-obatan penurun gula oral dan pengelolaan gaya hidup tidak optimal. Pemberian insulin 
dengan memperhatikan inisiasi atau peningkatan dosis insulin untuk melihat hasil tanggapannya. Insulin merupakan satu opsi yang tersedia untuk membantu manajemen diabetes mereka dan diperlukan cara memelihara kendali gula darah, khusunya dalam jangka lebih panjang.

Berdasarkan karakteristik umur pasien, dapat diketahui bahwa responden dalam katagori kurang didominasi oleh responden berusia antara $>65$ tahun yaitu berjumlah 20 orang (25\%). Berdasarkan karakteristik umur keluarga dapat diketahui bahwa responden dalam katagori kurang didominasi oleh responden berusia antara $46-55$ tahun yaitu 15 orang $(18,8 \%)$. Penelitian ini sesuai dengan teori yang dinyatakan oleh Julianan et al (2010) tentang hubungan usia dengan pengetahuan yang menyatakan semakin muda usia individu maka kemampuan mengingat akan semakin tinggi terutama kemampuan untuk mengingat informasi yang diterima.

Berdasarkan karakteristik jenis kelamin pasien diketahui bahwa mayoritas responden dalam katagori kurang didominasi oleh responden yang berjenis kelamin perempuan yaitu sebanyak 29 orang (36,3\%). Berdasarkan karakteristik jenis kelamin pada keluarga, diketahui bahwa mayoritas responden dalam katagori kurang didominasi oleh responden yang berjenis kelamin laki-laki yaitu sebanyak 22 orang $(27,5 \%)$. Hal ini mendapat hasil yang sama dengan penelitian Ifada (2010) yang mengatakan bahwa pengetahuan masyarakat di negara berkembang terutama perempuan lebih rendah berkaitan dengan hambatan dalam mengakses informasi, seperti kondisi masyarakat yang belum produktif, cara berproduksi dan pola perekonomian yang dijalankan masih tradisional, system dan pola kerja yang telah ada masih bersifat tradisi/turun-temurun, perekonomian dilakukan untuk memenuhi kebutuhan sendiri dan pencaharian masyarakat di sektor pertanian. Hal ini berbeda dengan penelitian oleh Arisma (2018) dimana skor responden perempuan lebih tinggi disbanding laki-laki yaitu $64 \%$, dimana dalam penelitiannya $90 \%$ wanita bekerja sebagai ibu rumah tangga sehingga media informasi seperti banyak menonton televisi dan aktivitasnya dalam bidang sosial lebih banyak sehingga proses diskusi dan pertukaran informasi dan pikiran lebih banyak daripada laki-laki.

Karakteristik berdasarkan tingkat pendidikan pasien, mayoritas responden yang memiliki pengetahuan kurang didominasi oleh responden yang tidak sekolah yaitu sebanyak 21 orang $(26,3 \%)$. Karakteristik berdasarkan tingkat pendidikan terakhir keluarga, mayoritas responden yang memiliki penegtahuan kurang didominasi oleh responden yang tingkat pendidikan SMA yaitu sebanyak 19 orang $(23,8 \%)$. Pada penelitian terhadap pasien, mayoritas responden yang tidak sekolah memiliki pegetahuan dalam katagori kurang. Hal ini sejalan dengan penelitian oleh Arisma (2018) yaitu responden dengan pendidikan rendah sehingga pengetahuannya masuk dalam katagori kurang. Menurut Hary (dalam Hanifah, 2010) bahwa tingkat pendidikan turut pula menentukan mudah tidaknya seseorang menyerap dan memahami pengetahuan yang mereka peroleh. Sementara, penelitian terhadap keluarga menunjukan responden dengan tingkat pendidikan SMA mayoritas masuk dalam katagori kurang, berarti hal ini tidak sesuai dengan pendapat Legumen (2013) yang menyatakan orang yang memiliki tingkat pendidikan tinggi biasanya akan memiliki pengetahuan tentang kesehatan. Sehingga dalam penelitian ini memiliki pendidikan tinggi, belum tentu pula memiliki pengetahuan baik tentang kesehatan, karena disamping pendidikan juga 
terdapat faktor lain yang mempengaruhi pengetahuan tersebut seperti pernah atau tidaknya terpapar informasi mengenai kesehatan itu sendiri

Menurut karakteristik lama menderita DM, diketahui bahwa sebagian besar responden yang berpengetahuan kurang didominasi oleh responden yang menderita $\mathrm{DM}>4$ tahun yakni sebanyak 38 orang (47,5\%). Lamanya seseorang menderita mempengaruhi seseorang dalam melakukan manajemen DM dibandingkan dengan seseorang yang baru menderita. Dimana seseorang yang telah lama menderita DM mempunyai pengalaman yang lebih banyak Ermawati (2011). Namun, hal ini justru berbanding terbalik dengan hasil dalam penelitian ini, dimana mayoritas responden yang menderita $>4$ tahun adalah responden yang memiliki pengetahuan kurang.

Berdasarkan karakteristik sumber informasi yang diperoleh pasien diketahui bahwa responden yang dalam katagori kurang didominasi responden yang memperoleh informasi dari petugas kesehatan yaitu sebanyak 31 orang $(38,8 \%)$. Menurut karakteristik sumber informasi yang diperoleh keluarga diketahui bahwa responden yang dalam katagori kurang didominasi responden yang tidak memperoleh informasi yaitu sebanyak 27 orang $(38,8 \%)$. Hasil penelitian pada pasien yang telah mendapat informasi namun mayoritas berpengetahuan kurang. Hasil ini tidak memiliki kesesuaian dengan teori Notoatmodjo (2010) yang menyatakan seseorang yang mempunyai informasi lebih banyak akan mempunyai pengetahuan yang lebih luas. Menurut peneliti hal ini karena informasi yang diberikan belum begitu dapat dipahami oleh responden karena berdasarkan hasil penelitian yaitu mayoritas responden tidak sekolah. Sesuai teori teori Wawan dan Dewi (2010) yang menyatakan bahwa semakin tinggi pendidikan seseorang tingkat memahami, menerima, dan mengelola informasi menjadi semakin baik. Sementara penelitian terhadap keluarga yang mayoritas memang tidak mendapat informasi, sehingga pengetahuannya juga dalam katagori kurang dan telah sesuai teori yang disebutkan Notoatmodjo di atas.

Hasil penelitian yang diperoleh menunjukan bahwa mayoritas penderita DM dan keluarga memiliki pengelolaan manajemen DM (pengobatan) dalam katagori kurang. Pengetahuan responden mayoritas dalam katagori kurang karena responden tidak mengetahui bahwa dalam menjaga kadar gula darah pada batas normal, obat tidak lebih penting daripada diet dan olahraga. Karena menurut responden hanya ketika mengkonsumsi obat saja gula darah akan terkendali.

\section{Simpulan}

\section{SIMPULAN DAN SARAN}

1. Distribusi gambaran pengetahuan pasien dan keluarga tentang edukasi di Wilayah Kerja Puskesmas Tabanan II tahun 2018 menunjukan bahwa mayoritas memiliki pengetahuan baik yaitu pasien 52 orang (65\%) dan keluarga 54 orang $(67,5 \%)$.

2. Distribusi gambaran pengetahuan pasien dan keluarga tentang diet di Wilayah Kerja Puskesmas Tabanan II tahun 2018 menunjukan bahwa sebagian besar responden yaitu pasien dan keluarga keduanya memiliki pengetahuan baik dimana pasien 67 orang $(83,8 \%)$, keluarga 58 orang $(72,5 \%)$.

3. Distribusi gambaran pengetahuan pasien dan keluarga tentang latihan fisik di Wilayah Kerja Puskesmas Tabanan II tahun 2018 menunjukan bahwa sebagian 
responden memiliki pengetahuan baik yaitu pada pasien sebanyak 62 orang $(77,5 \%)$, pada keluarga yaitu sebanyak 72 orang $(90 \%)$.

4. Distribusi gambaran pengetahuan pasien dan keluarga tentang pengobatan di Wilayah Kerja Puskesmas Tabanan II tahun 2018 menunjukan bahwa mayoritas responden dimana pasien maupun keluarga memiliki pengetahuan kurang yakni pada pasien sebanyak 49 orang $(61,3 \%)$ dan keluarga sebanyak 43 orang $(53,8 \%)$.

\section{Saran}

1. Tempat penelitian

Hasil penelitian menunjukan pada gambaran pengetahuan pasien dan keluarga tentang pengobatan DM masih dalam katagori kurang salah satunya karena faktor kurangnya sumber informasi. Dari pihak Puskesmas Tabanan II diharapkan dapat mengubah mindset pasien maupun keluarganya bahwa pelaksanaan diet dan olahraga lebih penting daripada penggunaan obat untuk menjaga keseimbangan kadar gula darah pasien. Keluarga ikut dilibatkan sebagai pengawas dalam pelaksanaan Manajemen DM Tipe 2, untuk itu keluarga juga membutuhkan informasi yang adekuat mengenai Manajemen DM Tipe 2. Untuk pelaksanaannya dapat dilakukan pada saat jadwal penyuluhan dengan menekankan pada pentingnya diet dan olahraga, ini juga dapat dilakukan pada saat pasien melakukan kunjungan ke puskesmas.

2. Bagi peneliti selanjutnya

Diharapkan dapat mengembangkan penelitian ini dengan menambahkan butir kuesioner pada variable diet, latihan fisik, dan pengobatan yang berkaitan dengan pengetahuan pasien dan keluarga tentang Manajemen DM Tipe 2, sehingga dapat mencakup secara detail semua aspek yang menyangkut variabel tersebut.

\section{Bagi pasien}

Diharapkan dapat mencari lebih banyak informasi serta mengimplementasikan tentang Manajemen DM Tipe 2 dengan tepat dan benar sesuai petunjuk dari petugas kesehatan yang didapatkan ketika konseling.

4. Bagi keluarga pasien

Keluarga diharapkan dapat meningkatkan pengetahuan dengan lebih aktif mencari informasi tentang Manajemen DM Tipe 2.

\section{DAFTAR PUSTAKA}

Amelia, dkk. 2014. Perbedaan Kejadian Disfungsi Seksual Pada Wanita Dengan Diabetes Melitus dan Tanpa Diabetes Melitus. Skripsi. Banjarmasin : Universitas Lambung Mangkurat Banjarmasin

Anggraini. 2016. Pengaruh Program Edukasi Dengan Media Audio Visual dan Tertulis Terhadap Perilaku Pencegahan Diabetes Melitus dan Kualitas Hidup Pada Warga Padukuhan Kasihan. Skripsi. Yogyakarta : Universitas Muhammadiyah Yogyakarta

Ardita, F. T. 2014. Gambaran Tingkat Pengetahuan dan Sikap Tentang Manajemen Insulin Pada Penderita DM di RS PKU Muhammadiyah Yogyakarta. 
Skripsi. Yogyakarta : Universitas Muhammadiyah Yogyakarta

Arisma, B. J. N. 2018. Gambaran Pengetahuan Masyarakat tentang Risiko Penyakit Diabetes Melitus di Kecamatan Pakisaji Kabupaten Malang. Skripsi. Malang : Universitas Negeri Malang

Dinas Kesehatan Propinsi Bali. 2011. Profil Kesehatan Propinsi Bali Tahun 2011. Bali : Dinas Kesehatan Propinsi Bali

Dinas Kesehatan Propinsi Bali. 2012. Profil Kesehatan Propinsi Bali Tahun 2012. Bali : Dinas Kesehatan Propinsi Bali

Dinas Kesehatan Propinsi Bali. 2016. Profil Kesehatan Propinsi Bali Tahun 2016. Bali : Dinas Kesehatan Propinsi Bali

Eka. 2016. Gambaran Dukungan Keluarga Dengan Ditinjau Dari Empat Dimensi Dukungan Keluarga Pada Pasien Diabetes Mellitus Tipe II di Wilayah Kerja Puskesmas Nanggalo Padang Tahun 2016. Skripsi. Padang: Universitas Andalas

Ermawati, Z. 2011. Gambaran Pengetahuan dan Sikap Tentang Pengelolaan Penyakitnya Pada Penderita Diabetes Melitus di Rumah Sakit Uum Daerah Panembahan Senopati Bantul. Skripsi. Yogyakarta : STIKES Aisyiyah Yogyakarta

Febty, I. 2014. Gambaran Pengetahuan Dan Perilaku Tentang Penatalaksanaan DM Pada Pasien DM di Puskesmas Ciputat Timur. Skripsi. Jakarta : Universitas Islam Negeri Syarif Hidayatullah Jakarta

Gloria, dkk .2013. Analisa Hubungan Antara Umur dan Riwayat Keluarga Menderita DM Dengan Kejadian Penyakit DM Tipe 2 Pada Pasien Rawat Jalan di Poliklinik Penyakit Dalam BLU RSUP Prof. Dr. R. D Kandou Manado. Srkipsi. Manado : Universitas Sam Ratulangi Manado

Gultom, Y.T. 2012. Tingkat Pengetahuan Pasien Diabetes Melitus Tentang Manajemen Diabetes Melitus di Rumah Sakit Pusat Angkatan Darat Gatot Subroto Jakarta Pusat. Skripsi. Jakarta : Universitas Indonesia

IDF. 2013. IDF Diabetes Atlas Sixth Edition, International Diabetes Federation 2013.http://www.idf.org/sites/default/files/EN_6E_Atlas_Full_0.pdf. Diakses tanggal 21 Februari 2018.

IDF. 2015. Diabetes Atlas Sixth Edition. International Diabetes Federation 2015. https://www.idf.org/sites/default/files/Atlas-poster-2015_EN.pdf. Diakses pada tanggal 15 Februari 2018

Ifada, I. 2010. Faktor-faktor yang berhubungan dengan Pengetahuan Masyarakat Mengenai Pelayanan Kesehatan Mata. Karya Tulis Ilmiah Strata Satu. Semarang : Universitas Diponegoro

Irawan, D. 2010. Prevalensi dan Faktor Risiko Kejadian Diabetes Melitus Tipe 2 di Daerah Urban Indonesia (Analisa Data Sekunder Riskesdas 2007). Tesis. Jakarta : Universitas Indonesia

Kemenkes Ri. 2013. Riset Kesehatan Dasar; RISKESDAS. Jakarta: Balitbang Kemenkes Ri

Kristianto, A., dkk.2012. Pengetahuan Sikap, dan Perilaku Perempuan Usia Reproduksi Terhadap Asuhan Antenatal, dan Faktor-faktor yang Berhubungan. Artikel Penelitian. Jakarta : Universitas Indonesia

Notoatmodjo, S. 2012. Metodologi Penelitian Kesehatan. Jakarta : Rineka Cipta.

Nugraheni, A. A. 2016. Gambaran Tingkat Pengetahuan Keluarga Tentang Diet Pasien Diabetes Melitus di Wilayah Kerja Puskesmas Kasihan 1 Bantul. 
Skripsi. Yogyakarta : Universitas Muhammadiyah

Nuryani, S. 2012. Gambaran Pengetahuan dan Perilaku Pengelolaan Penyakit Diabetes Melitus Pada Penderita Diabetes Melitus di Puskesmas Parit H. Husni II Pontianak Tahun 2011. Skripsi. Pontianak : Universitas Tanjungpura

Paulus. 2012. Gambaran Tingkat Pengetahuan Faktor Risiko Diabetes Melitus pada Mahasiswa Fakultas Eknomi Universitas Indonesia. Skripsi. Jakarta : Universitas Indonesia

Perkeni. 2015. Pengelolaan dan Pencegahan Diabetes Melitus Tipe 2 di Indonesia 2015. Jakarta: Perkumpulan Endokrinologi Indonesia.

Rasajati, Q., Bambang, B., Dina, N. A. N. 2015. Faktor-Faktor yang berhubungan dengan Kepatuhan Pengobatan pada Penderita Hipertensi di Wilayah Kerja Puskesmas Kedungmindu Kota Semarang. Unnes Journal of Public Health. Semarang : Universita Negeri Semarang

Riskesdas. 2013. Riset Kesehatan Dasar 2013. Jakarta: Badan Penelitian dan Pengembangan Kesehatan Kementerian Kesehatan Republik Indonesia.

Sonyo, S.H. 2016. Gambaran Pengetahuan dan Sikap Pengaturan Makan Penderita DM Tipe 2 di Wilayah Kerja Puskesmas Kendal. 02. Skripsi. Yogyakarta : Universitas Muhammadiyah Yogyakarta

Sumangkut S, Supit W, Onibala F. 2013. Hubungan Pola Makan Dengan Kejadian Penyakit Diabetes Melitus Tipe 2 di Poli BLU.RSUP. Prof. Dr. R. D. Kandaou Manado. E-journal Keperawatan (e-Kp). 1(1) : 1-6.

Susanti, M., dan Sulistyarini, T. 2013. Dukungan Keluarga Meningkatkan Kepatuhan Diet Pasien DM di Ruang Rawat Inap RS Baptis Kediri. Jurnal STIKES. 1(1) : 1-10.

Sutrisno, R. O. 2012. Studi Penggunaan Antidiabetes pada Pasien Diabtes Melitus Tipe 2 dengan Penyakit Jantung Koroner. Skripsi. Malang : Universitas Muhammadiyah Malang

Suyono, S. 2009. Diabetes Melitus di Indonesia : Buku Ajar Ilmu Penyakit Dalam Jilid III Edisi V. Jakarta. Balai Penerbit Fakultas Kedokteran Universitas Indonesia, Jakarta. $1134 \mathrm{hlm}$.

Tandra, H. 2008. Segala Sesuatu Yang Harus Anda Ketahui Tentang-Diabetes. Jakarta: PT Gramedia Pustaka Utama

Ulfa, M. 2015. Gambaran Pengetahuan Anggota Keluarga Berisiko Tentang Pencegahan Diabetes Melitus Tipe 2 Di Wilayah Kerja Puskesmas Pisagan. Skripsi. Jakarta : Universitas Islam Negeri Syarif Hidayatullah Jakarta

Warsito. 2016. Gambaran Pengetahuan tentang Senam Diabtes Melitus pada Pasien Diabetes Melitus Tipe 2 di Puskesmas Karangpandan Karanganyar. Skripsi. Surakarta : STIKES Kusuma Husada Surakarta

Wawan, A dan Dewi, M. 2010. Teori dan Pengukuran Pengetahuan, Sikap dan Perilaku Manusia.. Yogyakarta : Nuha Medika. 